\title{
THIN-WALLED CROSS SECTION SHAPE INFLUENCE ON STEEL MEMBER RESISTANCE
}

\author{
Elżbieta Urbańska-Galewska', Patryk Deniziak'1, Małgorzata Gordziej-Zagórowska', \\ Agnieszka Łukowicz'
}

1 Faculty of Civil and Environmental Engineering, Gdańsk University of Technology, Narutowicza St. 11/12, 80233 Gdańsk, Poland, e-mail: ugalew@pg.gda.pl, patdeniz@pg.gda.pl, malgor@pg.gda.pl, agnlukow@pg.gda.pl

Received: 2015.10 .30

Accepted: 2016.02.01

Published: 2016.03.01

\begin{abstract}
This work describes why trending thin-walled technology is achieving popularity in steel construction sector. A purpose of this article is to present the influence of the cold-formed element cross-section shape on an axial compression and a bending moment resistance. The authors have considered four different shapes assuming constant section area and thickness. Calculations were based on three different steel grades taking into account local, distortional and overall buckling. The results are presented in a tabular and a graphical way and clearly confirm that cross-section forming distinctly impact the cold-formed member resistance. The authors choose these cross-sections that work better in compression state and the other (those slender and high) that function more efficiently are subjected to bending.
\end{abstract}

Keywords: steel structures, thin-walled elements, efficient shape research.

\section{INTRODUCTION}

An aspiration to be competitive on the global market forces entrepreneurs to find new solutions allowing to reduce production costs and there is no difference in the construction industry as well. Concrete, wood and steel structures compete with each other causing a development in the sector. Constant surveys allow to understand building materials complex features better and push its strength calculation accuracy closer to the physical limit. Massive, steel structures have been widely used for decades and the presence of steel bridges or industry buildings in our environment has become quite common. Nowadays, many production companies need more cheap storage space and we can observe a growing demand for light and durable steel constructions. Designers' response to this requirement is applying thin, cold-formed framing constructions. But also due to economic reasons such as shortening investment time and reducing labour costs, wood trusses in residential buildings are replaced by a steel equivalents what is also described in Zaharia's and Dubina's paper [1].

Only when a European Standard [2] was published in 2006 engineers received reliable, complex but complicated methods to determine the resistance of thin-walled members whose thickness starts from $0.45 \mathrm{~mm}$. A maximum width-tothickness ratio of a plane element is defined and has to be obeyed otherwise the computation must be verified by tests on structures. Typical cross sections are shown in Figure 1.

Cold-formed members are made from coated or uncoated steel sheet and strip by cold-rolled forming or press-braking. Designers have a freedom of shaping structural bars so consequently many companies reserve the right to previously patented shape creating their own, unique system. Shape issue is not only a question of copyrights but it also has a significant impact on section strength.

The purpose of this article is to present the influence of cross-section shape on an axial compression and a bending moment resistance. 


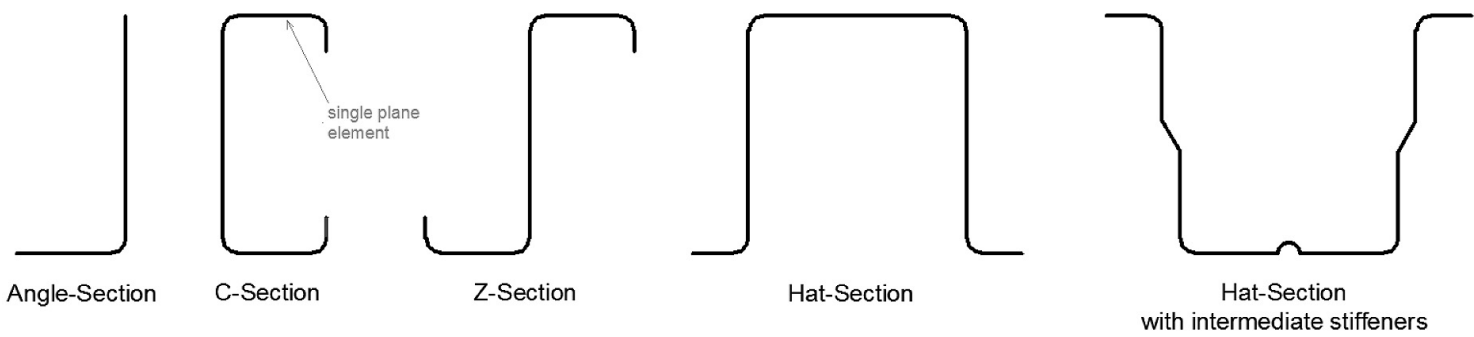

Fig. 1. Typical cold-formed bar cross sections

\section{COMPUTATION ASSUMPTIONS}

Calculations were based mainly on [2] but also on a Brune and Pekoz's [3], Camotim and Basaglia's [4] and example calculations presented in a Goczek's book [5]. Constant dimensions and thickness of a steel sheet were authors' fundamental assumptions due to technological and financial limitations such as bending machine dimensions and minimizing sheet metal waste. Four different bended shapes presented in Figure 2 were selected to analysis. The third cross-section (Fig. 2c) is very often applied as a chord or web members utilized in some steel trusses, what is described in Gordziej's [6]. Section number four (Fig. 2d) is the author's optimized shape called GEB used during previous tests on structures what is presented in Łukowicz's [7].

It was assumed that a plate thickness $\mathrm{t}=2 \mathrm{~mm}$ and sheet width equals $400 \mathrm{~mm}$ giving a crosssection area $\mathrm{A}=8 \mathrm{~cm}^{2}$. Three steel grades were taken into account: DC04 (according to Ruukki catalogue [8]) $\mathrm{f}_{\mathrm{y}}=210 \mathrm{MPa}, \mathrm{S} 235 \mathrm{f}_{\mathrm{y}}=235 \mathrm{MPa}$ and continuous hot dip zinc coated steel S350 $\mathrm{GD}+\mathrm{Zf}_{\mathrm{y}}=350 \mathrm{MPa}$. Firstly, computations consider local and distortional buckling giving a resistance of a cross-section as a result and then overall buckling was implemented. According to [2] each of the selected sections is classified as a fourth class (very slender) and is sensitive to buckling, what is noticeable in results. Plane elements with edge stiffeners were refined iteratively as well. Consequently, we can only computationally use an idealized, effective cross-section which is different in bending and axial

\section{RESULTS}

The axial compression and bending moment resistance of selected cross-sections (Figure 2) has been obtained. Calculations were repeated for each steel grade. The results are shown in Table 1. A 180-degree section turn causes getting different bending resistance because a tension arrangement also reverses so local and distortional buckling
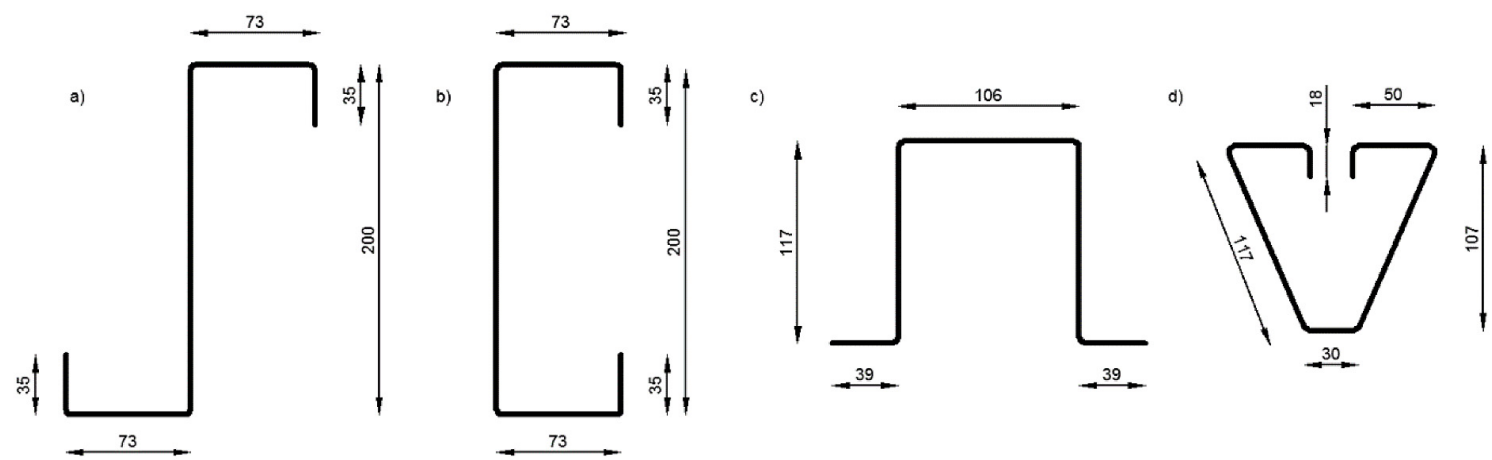

Fig. 2. Selected to analysis bending thin-walled shapes

a)

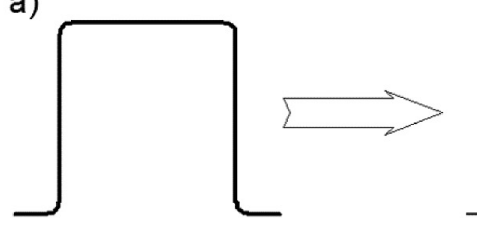

b)

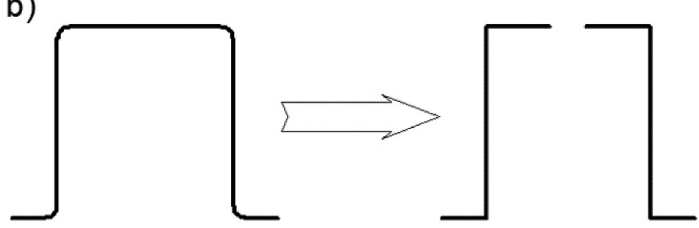

Fig. 3. Computation effective cross-section in the case of hat-section a) axial compression b) bending 
Table 1. Axial compression and bending moment resistance of selected cross-sections compression conditions what is shown graphically in Figure 3

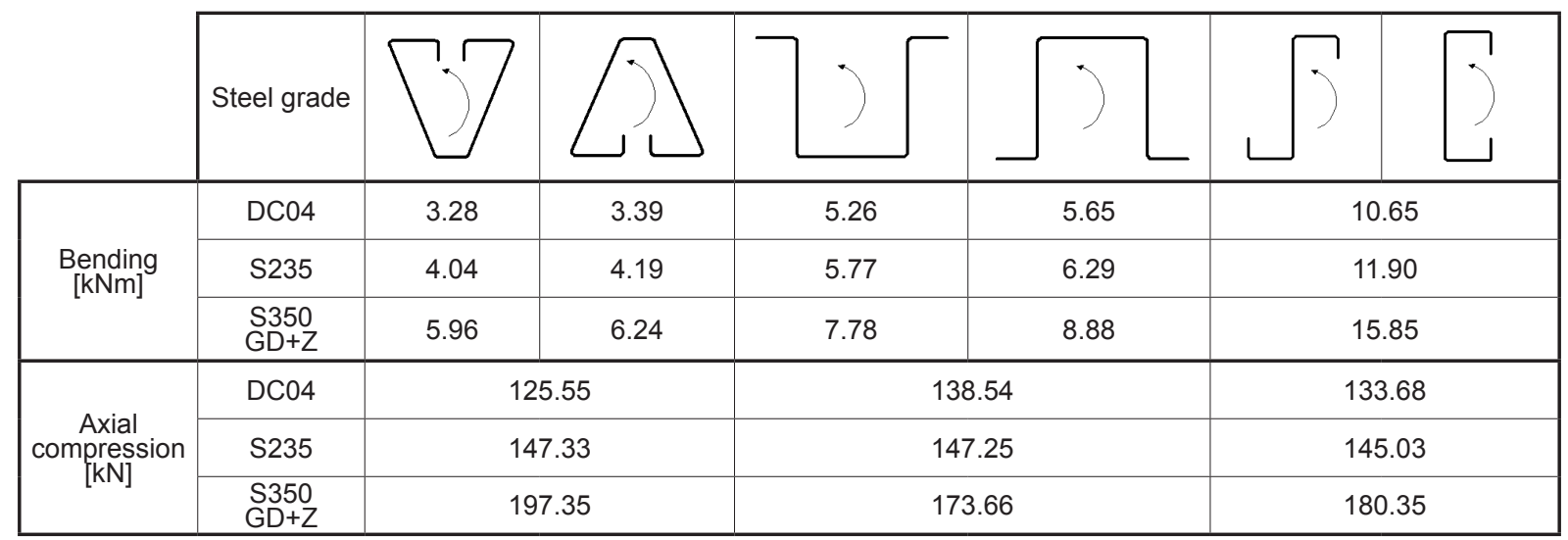

influences other elements of a cross-section what is clearly visible comparing to the resistances instance of hat section. This turn may result in a $14 \%$ resistance increase.

Tensioned section parts (for represented by round arrows bending it is a bottom part) are not affected by buckling that is why Z- and C-sections have the same bending resistance.

A plate slenderness depends on a square root of the steel yield strength $f_{y}$, what makes computational and effective cross-section dimensions conditioned by steel grade in a nonlinear way. This curvilinear relation between cross-section bending moment resistance and steel grades is shown in Figure 4 on the graph in case of coldformed Z-section. Analogical relation for optimized GEB section is presented in Figure 5.

Besides a simple cross-section analysis there is even more important quantity-resistance of a member comprehensively. This computations need to take into account an overall buckling that decreases a resistance with the increase of the member length. Lateral-torsional buckling influ- ence on members subjected to bending is shown in Figure 6. It is clearly visible that slender Zsection has highest bending resistance but with the member length increasing its resistance drops significantly. After reaching 5,0 metres the length our Z-section is no longer a dominant. Hat- and GEB-sections which are lower are less prone to lateral-torsional buckling.

Figure 7 presents a relation between compression member overall resistance (including buckling) and the length. Pinned connections (hinged and free to rotate) on both ends were assumed so effective length factor $K=1.0$. As Hat- and GEB-section are open and mono-symmetric a torsional-flexural buckling had to be calculated and turned to be a decider. For point-symmetric, open Z-section flexural and torsional buckling were calculated individually what required principal cross-section axis defining. Under these conditions the results are less divergent so resistance depends on the section shape less significantly. There is, however, a distinct, curvilinear length influence on the overall resistance.

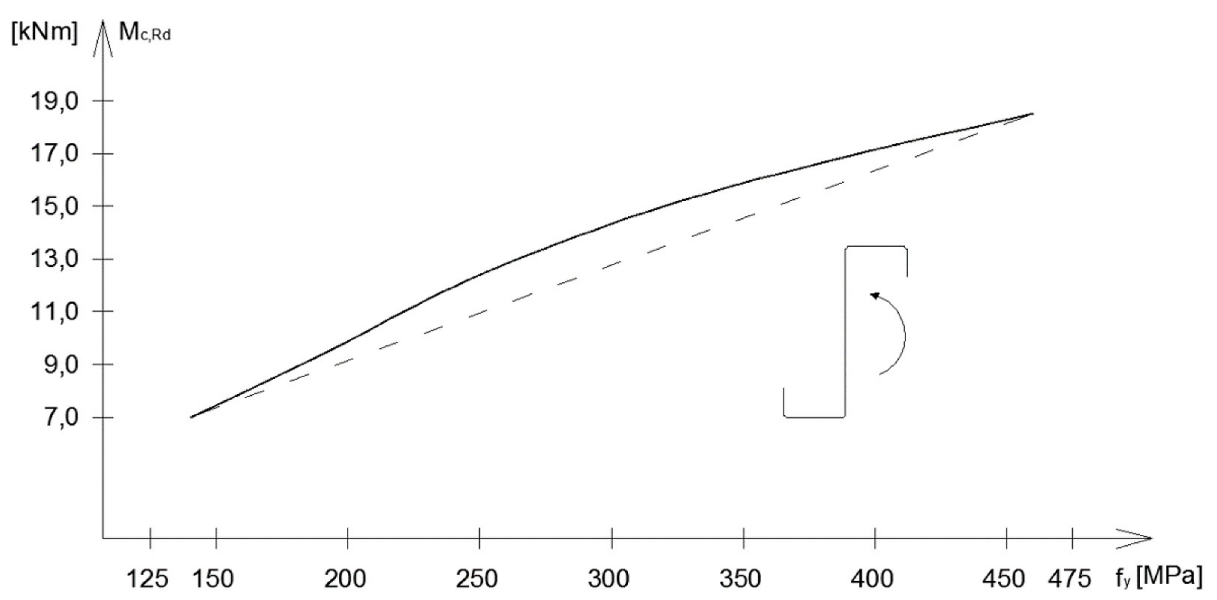

Fig. 4. A relation between bending moment resistance and steel grade for cold-formed Z-section 


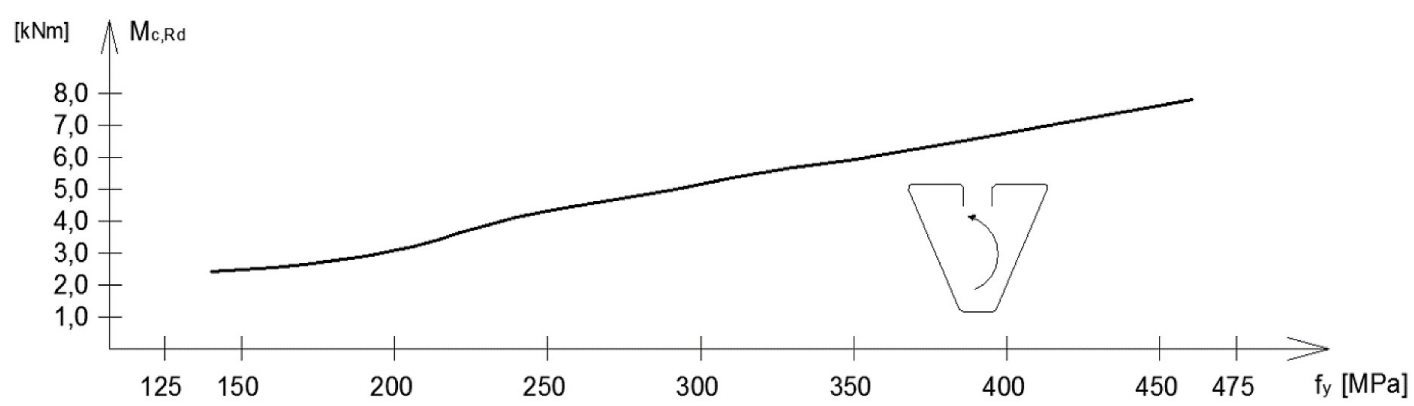

Fig. 5. A relation between bending moment resistance and steel grade for cold-formed GEB-section

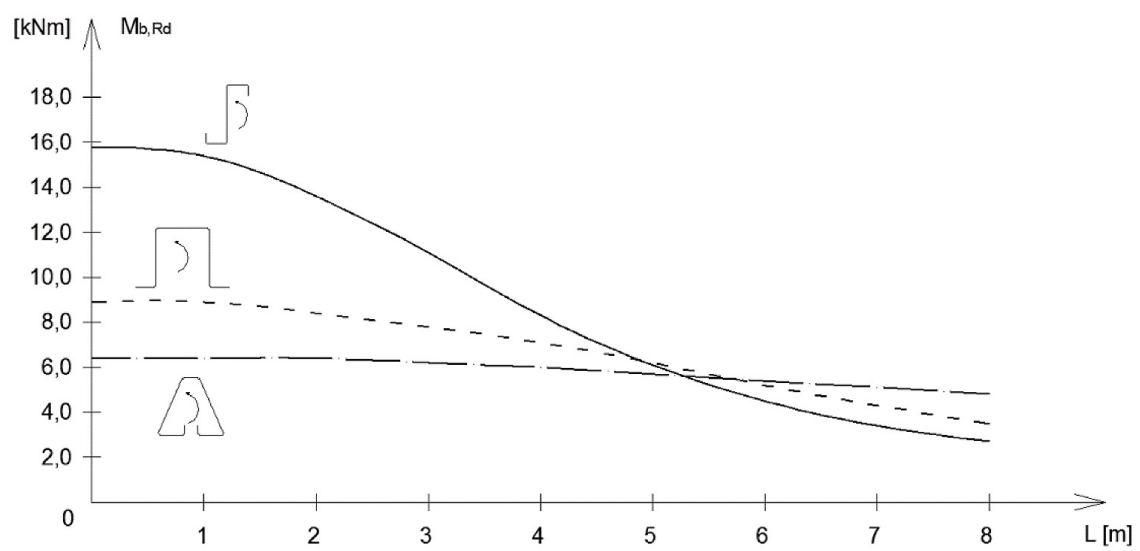

Fig. 6. A relation between overall bending moment resistance and member length

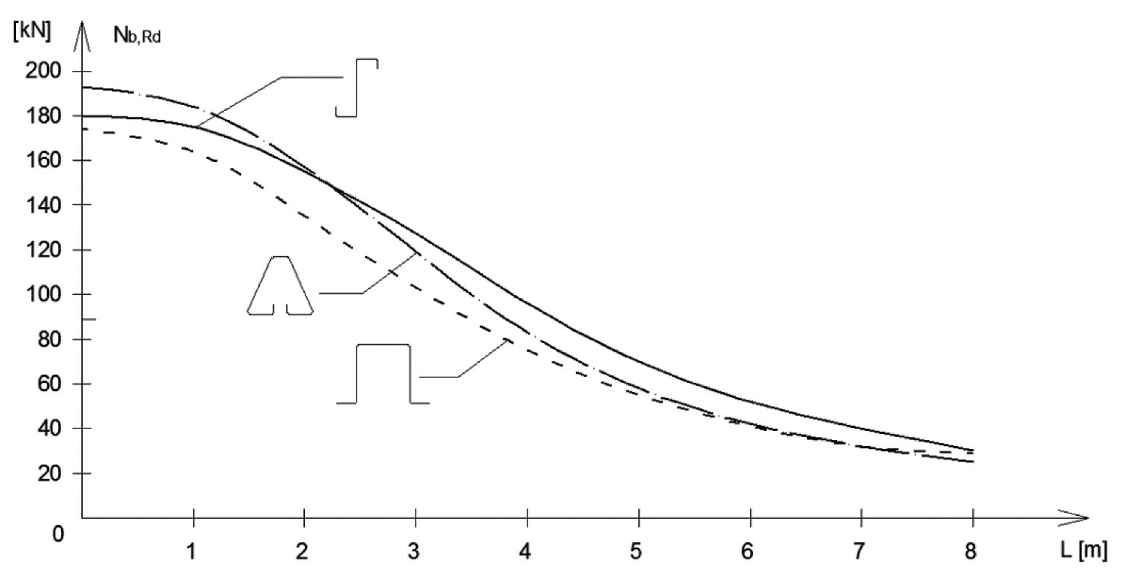

Fig. 7. A relation between overall buckling axial resistance and member length

\section{CONCLUSIONS}

Having to use a steel sheet with specific crosssection area there are many possibilities to form a thin-walled member shape. Authors computationally confirmed that the cross-section shape has a strong influence on cold-formed member resistance, mainly in bending. Longer elements of a cross-section with no stiffeners are prone to local and distortional buckling, decreasing the resistance of the cross-section. Longitudinal member dimension affects the overall resistance negatively as well.
Slender and high Z- and C-sections seem to be optimal bending form due to its relatively high radius of gyration. They are often used as purlins and furthermore they also work well as a compression member. Those compact Hat- and GEB sections, despite using the same amount of steel, have lower bending resistance because their section modulus is limited. But their overall buckling axial resistance is equal with the rest of sections. The authors claim that despite the complicated calculation method cold-formed members usage is well-founded because of their general diversity, versatility and flexibility. 


\section{REFERENCES}

1. Zaharia R., Dubina D. Stiffness of joints in bolted connected cold-formed steel trusses. Journal of Constructional Steel Research, 62, 2006, 240-249.

2. EN-1993-1-3 Design of steel structures - Supplementary rules for cold-formed members and sheeting.

3. Brune B., Peköz T. Design of cold-formed steel members - comparison of EN 1993-1-3 and Direct Strength Method. Steel Constr. 6, 2, 2013, 82-94.

4. Camotim D., Basaglia C. Buckling analysis of thin-walled steel structures using generalized beam theory (GBT): State-of-the-art report. Steel Construction $6,2,2013,117-131$.
5. Goczek J., Supeł Ł., Gajdzicki M. Przykłady obliczeń konstrukcji stalowych. Wydawnictwo Politechniki Łódźkiej, 2013.

6. Gordziej-Zagórowska M. The effect of load eccentricities of K-joints in steel trusses. Zeszyty Naukowe Politechniki Gdańskiej. Inżynieria Lądowa i Wodna, 625, 2012, 23-32.

7. Łukowicz A., Urbańska-Galewska E. Deformation of innovative cold-formed „GEB” section. Eurosteel, 2014.

8. Rautaruukki Corporation Catalogue. Zimnowalcowane blachy stalowe w arkuszach i kręgach. Stale przeznaczone do przeróbki plastycznej, 2006, 1-4. 